\title{
Sulfur Dioxide Relaxes Rat Aorta by Endothelium-Dependent and -Independent Mechanisms
}

\author{
Y.-K. WANG ${ }^{1}$, A.-J. REN ${ }^{1}$, X.-Q. YANG ${ }^{1}$, L.-G. WANG ${ }^{1}$, W.-F. RONG ${ }^{3}$, C.-S. TANG ${ }^{4}$, \\ W.-J. YUAN ${ }^{1,2}$, L. LIN ${ }^{1}$ \\ ${ }^{\#}$ These authors contributed equally to this paper.
}

${ }^{1}$ Department of Physiology, Second Military Medical University, Shanghai, ${ }^{2}$ School of Basic Medical Science, Ning-Xia Medical College, Yinchuan, ${ }^{3}$ Department of Physiology, School of Medicine, Shanghai Jiaotong University, Shanghai, ${ }^{4}$ Department of Physiology and Pathophysiology, Health Science Center, Peking University, Beijing, China

Received November 24, 2007

Accepted June 23, 2008

On-line July 25, 2008

\section{Summary}

This study aimed to investigate the vasoactivity of sulfur dioxide $\left(\mathrm{SO}_{2}\right)$, a novel gas identified from vascular tissue, in rat thoracic aorta. The thoracic aorta was isolated, cut into rings, and mounted in organ-bath chambers. After equilibrium, the rings were gradually stretched to a resting tension. Isometric tension was recorded under the treatments with vasoconstrictors, $\mathrm{SO}_{2}$ derivatives, and various drugs as pharmacological interventions. In endothelium-intact aortic rings constricted by $1 \mu \mathrm{M}$ phenylephrine $(\mathrm{PE}), \mathrm{SO}_{2}$ derivatives $(0.5-8 \mathrm{mM})$ caused a dosedependent relaxation. Endothelium removal and a NOS inhibitor L-NAME reduced the relaxation to low doses of $\mathrm{SO}_{2}$ derivatives, but not that to relatively high doses ( $\geq 2 \mathrm{mM}$ ). In endotheliumdenuded rings, $\mathrm{SO}_{2}$ derivatives attenuated vasoconstriction induced by high $\mathrm{K}^{+}(60 \mathrm{mM})$ or $\mathrm{CaCl}_{2}(0.01-10 \mathrm{mM})$. The relaxation to $\mathrm{SO}_{2}$ derivatives in $\mathrm{PE}$-constricted rings without endothelium was significantly inhibited by blockers of ATPsensitive $\mathrm{K}^{+}\left(\mathrm{K}_{\text {ATP }}\right)$ and $\mathrm{Ca}^{2+}$-activated $\mathrm{K}^{+}\left(\mathrm{K}_{\mathrm{Ca}}\right)$ channels, but not by those of voltage-dependent $\mathrm{K}^{+}$channels, $\mathrm{Na}^{+}-\mathrm{K}^{+}$-ATPase or $\mathrm{Na}^{+}-\mathrm{Ca}^{2+}$ exchanger. $\mathrm{SO}_{2}$ relaxed vessel tone via endotheliumdependent mechanisms associated with NOS activation, and via endothelium-independent mechanisms dependent on the inhibition of voltage-gated $\mathrm{Ca}^{2+}$ channels, and the opening of $\mathrm{K}_{\text {ATP }}$ and $\mathrm{K}_{\mathrm{Ca}}$ channels.

\section{Key words}

Sulfur dioxide • Vasorelaxation • Ion channel • Endothelium • Aorta • Rat

\section{Corresponding author}

W.-J. Yuan/L. Lin, Department of Physiology, Second Military Medical University, Shanghai 200433, China. E-mail: yuanwj@hotmail.com

\section{Introduction}

The vascular endothelium has been established as an abundant source of vasoactive substances including gases, such as nitric oxide (NO), carbon oxide (CO) and sulfureted hydrogen $\left(\mathrm{H}_{2} \mathrm{~S}\right)$ (Bhatia 2005). Sulfur dioxide $\left(\mathrm{SO}_{2}\right)$ is a novel gas first detected in porcine coronary artery by Balazy et al. (2003). A possible precursor of $\mathrm{SO}_{2}$ could be the intracellular thiol such as cysteine that can be oxidized to cysteinesulfinic acid by cysteine dioxygenase. Cysteinesulfinate can further be transformed by glutamate-oxaloacetate transaminase to generate $\beta$-sulfinylpyruvate, which decomposes spontaneously to pyruvate and $\mathrm{SO}_{2}$ (Griffith 1983). Another pathway that can produce $\mathrm{SO}_{2}$ is the oxidation of $\mathrm{H}_{2} \mathrm{~S}$ by NADPH oxidase (Mitsuhashi et al. 2005).

Little is known about the vasoactivity of $\mathrm{SO}_{2}$. A few studies addressed the systemic impact of $\mathrm{SO}_{2}$ inhalation under the concern that $\mathrm{SO}_{2}$ is a common air pollutant. Meng et al. (2003) reported that both $\mathrm{SO}_{2}$ inhalation and intraperitoneal injection of $\mathrm{SO}_{2}$ 
derivatives decreased blood pressure in rats, implying possible vasorelaxant activity of $\mathrm{SO}_{2}$. Besides, $\mathrm{ACh}$ was shown to stimulate the formation of $\mathrm{SO}_{2}$ (Balazy et al. 2003), raising a possibility that $\mathrm{SO}_{2}$ is involved in the profound vasodilation response to $\mathrm{ACh}$. However, the direct vasoactivity of $\mathrm{SO}_{2}$ has never been described.

$\mathrm{SO}_{2}$ is quite soluble in water. Upon solution, it hydrates rapidly to form sulfurous acid, which dissociates in turn to form sulfite and bisulfite ions (3:1 $\mathrm{M} / \mathrm{M}$, in neutral fluid) (Shapiro 1977). The present study observed that $\mathrm{SO}_{2}$ derivatives, a mixture of sulfite and bisulfite $\left(\mathrm{Na}_{2} \mathrm{SO}_{3} / \mathrm{NaHSO}_{3}\right)$ in a molar ratio of 3:1, elicited potent vasorelaxation in isolated rat aortic rings constricted by phenylephrine (PE) through both endothelium-dependent and -independent mechanisms. The endothelium-dependent relaxation induced by $\mathrm{SO}_{2}$ was revealed by denuding the endothelium and applying a NOS inhibitor $\mathrm{N}^{\mathrm{G}}$-nitro-L-arginine methyl ester (LNAME), and the endothelium-independent mechanism was further investigated by using a variety of ion channel interventions such as antagonist of $\mathrm{K}^{+}$channels, voltage-gated $\mathrm{Ca}^{2+}$ channels, $\mathrm{Na}^{+}-\mathrm{K}^{+}$pump and $\mathrm{Na}^{+}-$ $\mathrm{Ca}^{2+}$ exchange in endothelium-denuded aortic rings.

\section{Materials and Methods}

\section{Preparation of rat aortic rings}

This study was performed in accordance with the Guide for Care and Use of Laboratory Animals published by the U.S. National Academy Press in 1996 and the Guidelines for Animal Experiments of the Second Military Medical University, China.

Male Sprague-Dawley rats (250-350 g) were anesthetized by intraperitoneal injection of $1 \mathrm{~g} / \mathrm{kg}$ urethane with $750 \mathrm{U}$ heparin. The thoracic aorta was quickly removed, cleaned of all connective and fat tissue, and cut into rings of $3 \mathrm{~mm}$ in length. The aortic rings were then mounted in organ-bath chambers containing modified Krebs-Henseleit (K-H) solution $(\mathrm{pH} 7.4)$ at $37{ }^{\circ} \mathrm{C}$, continuously bubbled with $95 \% \mathrm{O}_{2}-5 \% \mathrm{CO}_{2}$. The modified K-H solution contained (in $\mathrm{mM}$ ): $\mathrm{NaCl}$ $118, \mathrm{KCl}$ 4.6, $\mathrm{MgSO}_{4} 1.2, \mathrm{KH}_{2} \mathrm{PO}_{4} 1.2$, glucose 11.1, $\mathrm{NaHCO}_{3}$ 27.2, EGTA 0.03, $\mathrm{CaCl}_{2}$ 1.8. After 30-min equilibrium, the rings were gradually stretched to a resting tension of $2 \mathrm{~g}$ over $40 \mathrm{~min}$. Isometric tension was recorded with force displacement transducers coupled to a computerized recording system (Nanjing MedEase Science and Technology Co. LTD, Nanjing, China).

\section{Protocols}

After two challenges with $60 \mathrm{mM} \mathrm{KCl}$, aortic rings were constricted by $1 \mu \mathrm{M}$ phenylephrine (PE) and subsequently challenged with $1 \mu \mathrm{M}$ acetylcholine (ACh) to confirm the integrity or removal of the endothelium. Then they were washed in K-H solution to restore tension to baseline level and allowed to stabilize for 60-90 min. The rings were constricted submaximally by $1 \mu \mathrm{M}$ phenylephrine (PE) again, and $\mathrm{SO}_{2}$ derivatives $\left(\mathrm{Na}_{2} \mathrm{SO}_{3}\right.$ and $\mathrm{NaHSO}_{3}, 3: 1 \mathrm{M} / \mathrm{M}$ ) were added cumulatively into the bathing solution once steady contraction was obtained. The equivalent $\mathrm{SO}_{2}$ concentration ranged from 0.5 to $8 \mathrm{mM}$. We have examined the $\mathrm{pH}$ of the Krebs solution that it is about 7.40 under normal conditions. After we add $\mathrm{SO}_{2}$ derivates at the lower concentrations $(0.5 \sim 2 \mathrm{mM})$, the $\mathrm{pH}$ does not change. It will decrease to 7.37 after $\mathrm{SO}_{2}$ derivates added at the higher concentrations $(4 \sim 8 \mathrm{mM})$ and can return to 7.40 in 3-4 min. Relaxation was calculated as a percentage of the maximal tension induced by PE (Engler et al. 2000).

The role of endothelium/nitric oxide (NO) in vasorelaxant responses to $\mathrm{SO}_{2}$ derivatives was first examined. For this set of experiments, the endothelium was removed mechanically by gently rubbing the luminal surface of aortic rings with a wire, and the functional removal was confirmed by the lack of relaxation in response to $\mathrm{ACh}$ as aforementioned. To examine the involvement of $\mathrm{NO}$, endothelium-intact rings were exposed for $30 \mathrm{~min}$ to a non-specific NOS inhibitor L-NAME ( $\mathrm{N}^{\mathrm{G}}$-nitro-L-arginine methyl ester, $\left.100 \mu \mathrm{M}\right)$ before the addition of PE.

To study the participation of $\mathrm{K}^{+}$channels in endothelium-independent relaxation induced by $\mathrm{SO}_{2}$ derivatives, aortic rings without endothelium were constricted with high $\mathrm{K}^{+}(60 \mathrm{mM}$, to abolish the effect of $\mathrm{K}^{+}$channel activation) (Sang et al. 2003), and $\mathrm{SO}_{2}$ derivatives were applied cumulatively. To further identify the types of $\mathrm{K}^{+}$channels associated with $\mathrm{SO}_{2}$, a $\mathrm{K}_{\mathrm{ATP}}$ blocker glibenclamide $(3 \mu \mathrm{M}), \quad$ a $\quad \mathrm{K}_{\mathrm{Ca}}$ blocker tetraethylammonium chloride (TEA, $5 \mathrm{mM}$ ) or a $\mathrm{K}_{\mathrm{V}}$ blocker 4-aminopyridine (4-AP, $100 \mu \mathrm{M}$ ) were applied to endothelium-denuded rings $30 \mathrm{~min}$ prior to the addition of PE. Only one concentration-response curve to $\mathrm{SO}_{2}$ derivatives was obtained per ring in the presence of each inhibitor.

The ability of $\mathrm{SO}_{2}$ to modulate $\mathrm{Ca}^{2+}$ influx via VGCCs was studied using $\mathrm{CaCl}_{2}$-constricted rings without endothelium, as described previously (Chan et al. 2005). For this set of experiments, two consecutive 
concentration-dependent constrictions to $\mathrm{CaCl}_{2}$ were obtained in the absence and in the presence of $\mathrm{SO}_{2}$ derivatives (0.5-8 $\mathrm{mM}, 5-\mathrm{min}$ incubation). For constructing $\mathrm{CaCl}_{2}$ concentration-response curve, arterial rings were rinsed three times in $\mathrm{Ca}^{2+}$-free solution containing $30 \mathrm{mM} \mathrm{Na}$-EGTA and then incubated in $\mathrm{Ca}^{2+}$-free, $60 \mathrm{mM} \mathrm{K}{ }^{+}$solution before the cumulative addition of $\mathrm{CaCl}_{2}$ (0.01-10 mM). The effect of $1 \mu \mathrm{m}$ nifedipine was tested as control.

In the final set of experiments, the rings were constricted with $1 \mu \mathrm{M}$ PE and relaxed with cumulative $\mathrm{SO}_{2}$ derivatives $(0.5-8 \mathrm{mM}) . \mathrm{Na}^{+}-\mathrm{K}^{+}$-ATPase inhibitor ouabain $(100 \mathrm{mM})$ or $\mathrm{Na}^{+}-\mathrm{Ca}^{2+}$ exchanger inhibitor nickel chloride $(30 \mu \mathrm{M})$ was applied $30 \mathrm{~min}$ prior to the addition of $\mathrm{PE}$.

\section{Drugs}

All the drugs were purchased from SigmaAldrich (St Louis, MO, USA). They were dissolved in $\mathrm{K}-\mathrm{H}$ solution except for glibenclamide, which was dissolved in dimethyl sulfoxide first and diluted with $\mathrm{K}-\mathrm{H}$ solution before use. The final content of dimethyl sulfoxide was $0.2 \%(\mathrm{v} / \mathrm{v})$, which did not affect vessel tension.

\section{Statistical analyses}

All data are presented as means \pm S.E.M. $\mathrm{SO}_{2}$ induced relaxation is expressed as the percentage change from the PE-contracted levels of tension. One-way repeated-measures ANOVA was used for comparisons of concentration-response curves. One-way ANOVA was used for comparisons at each drug concentration. $P<0.05$ value was considered significant.

\section{Results}

$\mathrm{SO}_{2}$ derivatives relaxed aortic rings by endotheliumdependent and-independent mechanisms

The thoracic aortic rings were equilibrated for 60-90 $\mathrm{min}$ at the optimal preload of $2 \mathrm{~g}$, and then cumulative concentrations of $\mathrm{SO}_{2}$ derivatives $(0.5,1,2,4$, $8 \mathrm{mM}$ ) were administered. No relaxation or constriction was observed (data not shown).

The vasoconstriction induced by $1 \mu \mathrm{M}$ PE was progressively relaxed by cumulative $\mathrm{SO}_{2}$ derivatives (0.5-8 $\mathrm{mM})$ in both endothelium-intact and -denuded rings. Figure 1A shows representative recordings. Lower concentrations of $\mathrm{SO}_{2}$ derivatives $(0.5$ and $1 \mathrm{mM})$ caused less relaxation in endothelium-denuded rings than that in endothelium-intact rings $(P<0.01$, Fig. 1B). However, relatively higher concentrations of $\mathrm{SO}_{2}$ derivatives $(2,4$ and $8 \mathrm{mM}$ ) relaxed the rings with and without endothelium to the same extent (Fig. 1B). These data suggest that both endothelium-dependent and -independent relaxations are induced by $\mathrm{SO}_{2}$ derivatives at lower doses, while the endothelium-independent relaxation is predominantly displayed at higher doses.

In agreement with the phenomenon, a nonselective NOS inhibitor L-NAME $(100 \mu \mathrm{M})$ abolished the relaxation of endothelium-intact rings induced by lower doses of $\mathrm{SO}_{2}$ derivatives $(0.5$ and $1 \mathrm{mM})$, but failed to affect that by higher doses (Fig. 1). It is suggested that NOS pathway is involved in the endothelium-dependent relaxation induced by $\mathrm{SO}_{2}$ derivatives.

A
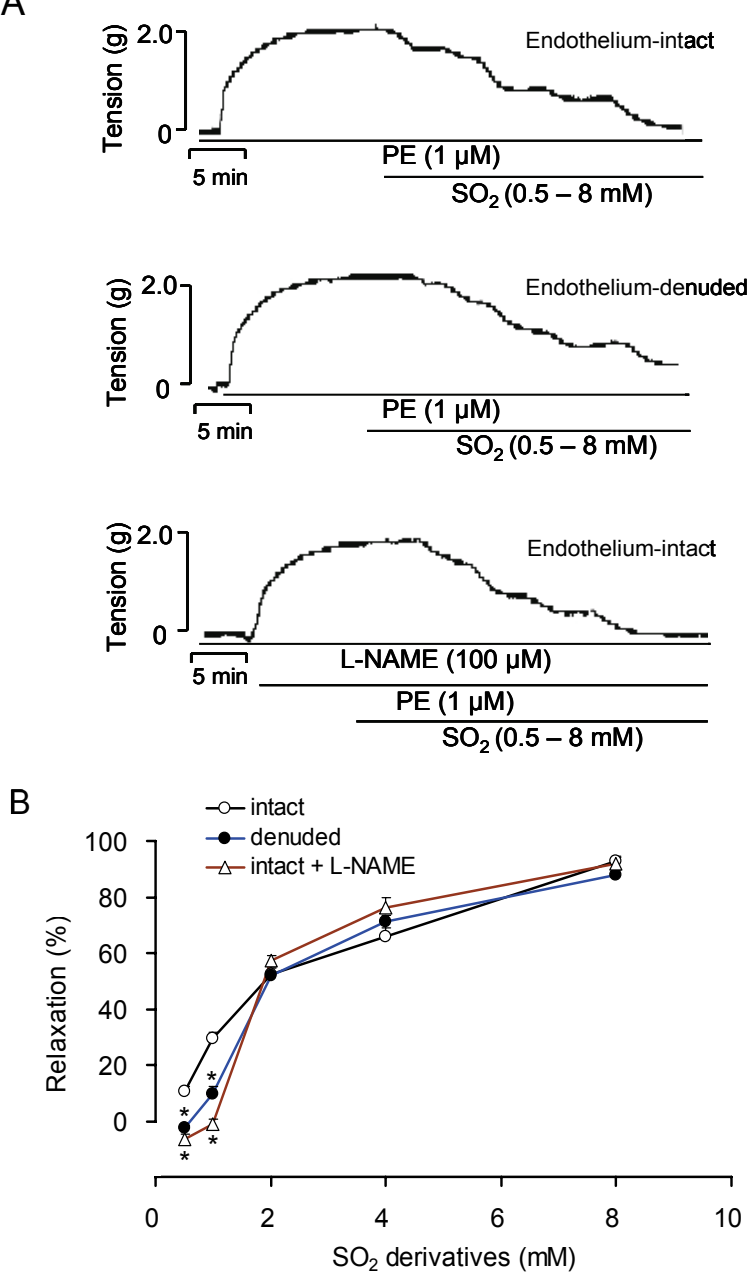

Fig. 1. Relaxation to $\mathrm{SO}_{2}$ derivatives $(0.5-8 \mathrm{mM})$ in rat thoracic aortic rings pre-constricted by $1 \mu \mathrm{M}$ phenylephrine (PE). (A) Representative traces of vessel tension in response to $P E$ and cumulative $\mathrm{SO}_{2}$ derivatives; (B) Relaxation curves in ( $\bigcirc$ ) endothelium-intact rings $(n=18),(\bullet)$ endothelium-denuded rings ( $n=18)$, and $(\triangle)$ endothelium-intact rings treated with $100 \mu \mathrm{M}$ of a non-specific NOS inhibitor L-NAME $(n=8)$. Results are mean \pm S.E.M. ${ }^{*} P<0.01$ vs. endothelium-intact rings. 
A
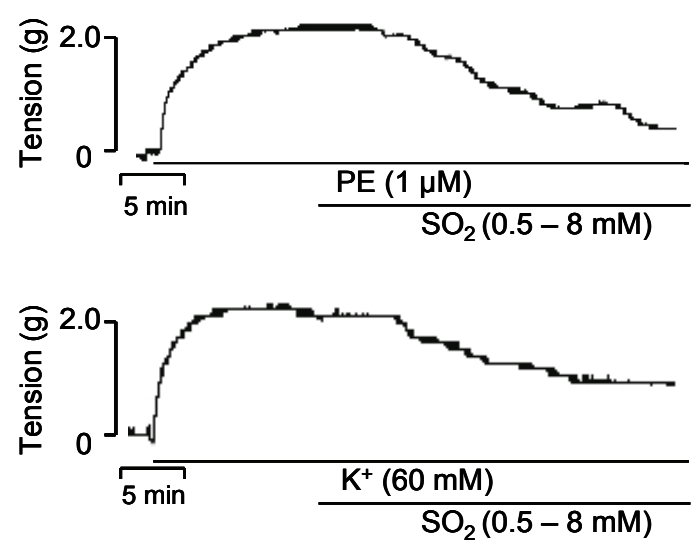

B

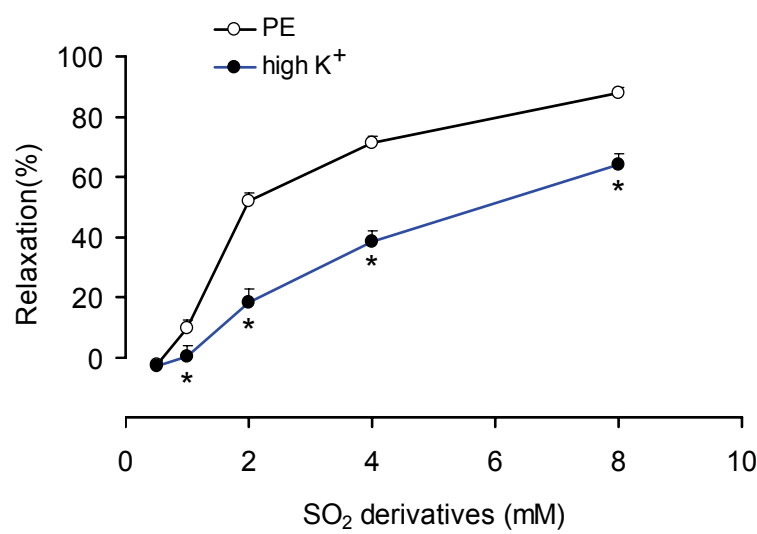

Fig. 2. Relaxation to $\mathrm{SO}_{2}$ derivatives $(0.5-8 \mathrm{mM})$ in endotheliumdenuded aortic rings preconstricted by $1 \mu \mathrm{M}$ phenylephrine $(\mathrm{PE}$, $\mathrm{n}=18$ ) or $60 \mathrm{mM} \mathrm{K}^{+}$(high $\mathrm{K}^{+}, \mathrm{n}=8$ ). (A) Representative traces of vessel tension; (B) Relaxation curves in rings pre-constricted by $1 \mu \mathrm{M}$ phenylephrine $(\mathrm{PE}, \bigcirc)$ or $60 \mathrm{mM} \mathrm{K}^{+}\left(\right.$high $\left.\mathrm{K}^{+}, \bullet\right)$. Results are mean \pm S.E.M. $* P<0.01$ vs. PE.

Ion channels involved in endothelium-independent relaxation induced by $\mathrm{SO}_{2}$ derivatives

\section{Involvement of $\mathrm{K}^{+}$channels}

In endothelium-denuded aortic rings constricted with $1 \mu \mathrm{M} \mathrm{PE}, \mathrm{SO}_{2}$ derivatives caused a dose-dependent relaxation with the maximum of $87.99 \pm 1.82 \%$ at $8 \mathrm{mM}$ (Fig. 2A). In the rings constricted with high $\mathrm{K}^{+}(60 \mathrm{mM})$, however, the relaxation to $\mathrm{SO}_{2}$ derivatives was significantly inhibited (maximum $63.88 \pm 3.78 \%$, $P<0.01$, Fig. 2B), though the contraction induced by high $\mathrm{K}^{+}$was comparable to that by PE (data not shown). On the one hand, the lessened vasorelaxant activity of $\mathrm{SO}_{2}$ derivatives suggests that the opening of $\mathrm{K}^{+}$channels contributes to the relaxation, since high $\mathrm{K}^{+}$is presumed to block all $\mathrm{K}^{+}$channels (Sang et al. 2003). On the other hand, the persistent existence of vasorelaxation in response to $\mathrm{SO}_{2}$ derivatives under high- $\mathrm{K}^{+}$conditions suggests that $\mathrm{K}^{+}$channel-independent mechanisms also

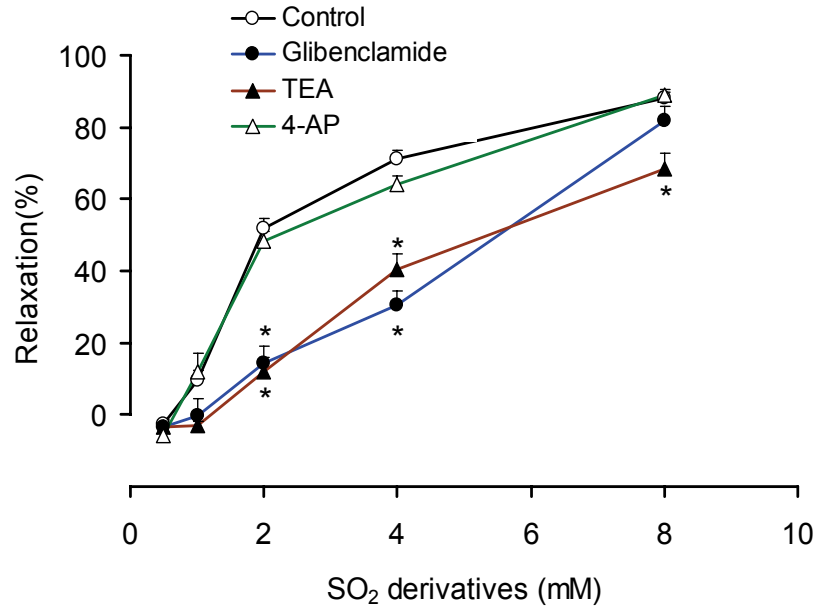

Fig. 3. Relaxation to $\mathrm{SO}_{2}$ derivatives $(0.5-8 \mathrm{mM})$ in endotheliumdenuded aortic rings preconstricted by $1 \mu \mathrm{M}$ PE. Glibenclamide $(3 \mu \mathrm{M}, \mathrm{n}=10)$, TEA $(5 \mathrm{mM}, \mathrm{n}=15)$ or 4 -AP $(100 \mu \mathrm{M}, \mathrm{n}=12)$ were incubated for 30 min before the addition of PE. Results are mean \pm S.E.M. $* P<0.01$ vs. control.

contribute to the relaxation.

To further identify the types of $\mathrm{K}^{+}$channels involved in $\mathrm{SO}_{2}$-induced relaxation, aortic rings without endothelium were treated with glibenclamide $(3 \mu \mathrm{M})$, TEA $(5 \mathrm{mM})$ and 4-AP $(100 \mu \mathrm{M})$ to block $\mathrm{K}_{\mathrm{ATP}}, \mathrm{K}_{\mathrm{Ca}}$ and $\mathrm{K}_{\mathrm{V}}$, respectively. The vasoconstriction induced by $\mathrm{PE}$ remained unchanged by the presence of glibenclamide, TEA or 4-AP. As shown in Figure 3, glibenclamide significantly reduced the relaxation caused by $4 \mathrm{mM}$ and $2 \mathrm{mM} \mathrm{SO}_{2}$ derivatives from $71.06 \pm 2.42$ to $30.54 \pm 4.05 \%$ $(P<0.01)$, and from $51.77 \pm 2.77$ to $14.44 \pm 4.63 \%$ $(P<0.01)$, respectively. Similarly, TEA significantly reduced the relaxation resulting from $4 \mathrm{mM}$ and $2 \mathrm{mM}$ $\mathrm{SO}_{2}$ derivatives to $40.36 \pm 4.22 \%(P<0.01)$ and $11.97 \pm$ $4.14 \%(P<0.01)$, respectively. Besides, the relaxant response to $8 \mathrm{mM} \mathrm{SO}_{2}$ derivatives was also significantly reduced by TEA $(68.62 \pm 4.27 \%$ vs. $87.99 \pm 1.82 \%$, $P<0.01)$. However, 4-AP did not affect the relaxation (n $=12, P>0.05$ vs. control). These data indicate that $\mathrm{SO}_{2}$-induced relaxation is associated with the opening of $\mathrm{K}_{\mathrm{ATP}}$ and $\mathrm{K}_{\mathrm{Ca}}$ channels in smooth muscle cells, but not $\mathrm{K}_{\mathrm{V}}$ channels.

\section{Involvement of voltage-gated $\mathrm{Ca}^{2+}$ channels}

In $\mathrm{Ca}^{2+}$-free, $60 \mathrm{mM} \mathrm{K}{ }^{+}$solution, cumulative $\mathrm{CaCl}_{2}(0.01-10 \mathrm{mM})$ induced progressive constriction of aortic rings without endothelium. The maximal tension was approximately $2.5 \mathrm{~g}$. $\mathrm{SO}_{2}$ derivatives $(0.5-8 \mathrm{mM})$ reduced $\mathrm{CaCl}_{2}$-induced constriction in a dose-dependent manner with progressive suppression of the maximal constriction ( $\mathrm{n} \geq 6$ for each group, Fig. 4). In control 


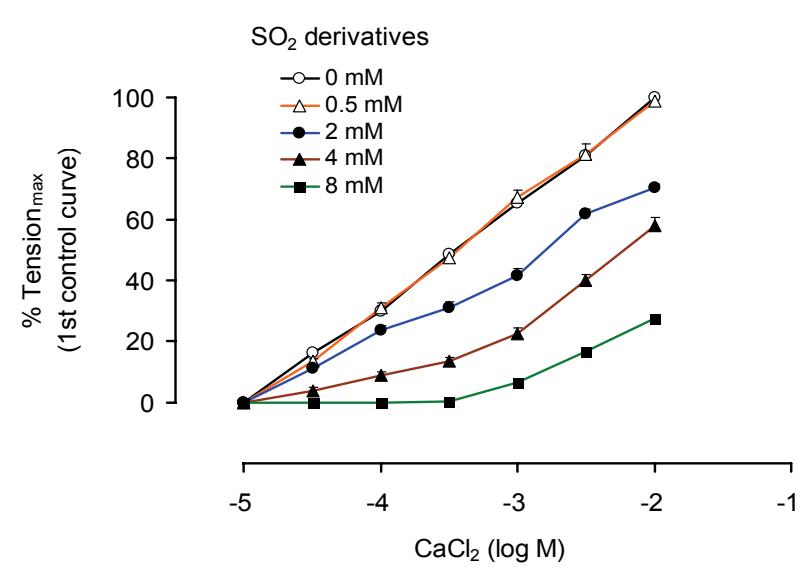

Fig. 4. $\mathrm{CaCl}_{2}$-induced contraction in $\mathrm{Ca}^{2+}$-free, $60 \mathrm{mM} \mathrm{K}^{+}$solution in the absence and presence of $\mathrm{SO}_{2}$ derivatives $(0.5-8 \mathrm{mM})$ in aortic rings without endothelium. Results are mean \pm S.E.M. of eight experiments.

experiments, $1 \mu \mathrm{M}$ nifedipine abolished vasoconstriction to $\mathrm{CaCl}_{2}$ (data not shown).

$\mathrm{No}$ involvement of $\mathrm{Na}^{+}-\mathrm{K}^{+}$pump and $\mathrm{Na}^{+}-\mathrm{Ca}^{2+}$ exchanger

Increased activity of $\mathrm{Na}^{+}-\mathrm{K}^{+}$pump results in a reduction in $\left[\mathrm{Na}^{+}\right]_{\mathrm{i}}$, which may stimulate the forward mode of $\mathrm{Na}^{+}-\mathrm{Ca}^{2+}$ exchanger and facilitate muscle relaxation. To test whether $\mathrm{SO}_{2}$-induced vasodilation is associated with the stimulation of $\mathrm{Na}^{+}-\mathrm{K}^{+}$pump or forward $\mathrm{Na}^{+}-\mathrm{Ca}^{2+}$ exchanger, the present study used a $\mathrm{Na}^{+}-\mathrm{K}^{+}$-ATPase inhibitor ouabain $(100 \mathrm{mM})$ and a putative $\mathrm{Na}^{+}-\mathrm{Ca}^{2+}$ exchanger inhibitor $\mathrm{Ni}^{2+}(30 \mu \mathrm{M})$. Neither ouabain nor $\mathrm{Ni}^{2+}$ affected the vasodilation resulting from $\mathrm{SO}_{2}$ derivatives in $\mathrm{PE}$-constricted aortic rings without endothelium (Fig. 5). It is suggested that $\mathrm{Na}^{+}-\mathrm{K}^{+}$pump and $\mathrm{Na}^{+}-\mathrm{Ca}^{2+}$ exchanger are not involved in the vasorelaxant response to $\mathrm{SO}_{2}$ derivatives.

\section{Discussion}

The vasoactivity of $\mathrm{SO}_{2}$ has never been described before, although it was found in vascular tissue (Balazy et al. 2003). The present study first revealed the direct vasorelaxant activity of $\mathrm{SO}_{2}$. In constricted rat aortic rings under isometric recording, we found that the derivatives of $\mathrm{SO}_{2}$ hydration, sulfite and hydrogen sulfite (Shapiro 1977), reduced vessel tension in a dosedependent manner. The vasorelaxation resulting from low doses of $\mathrm{SO}_{2}$ derivatives $(0.5$ and $1 \mathrm{mM})$ was attenuated by endothelium removal and a non-specific NOS inhibitor L-NAME (Fig. 1), indicating the involvement of

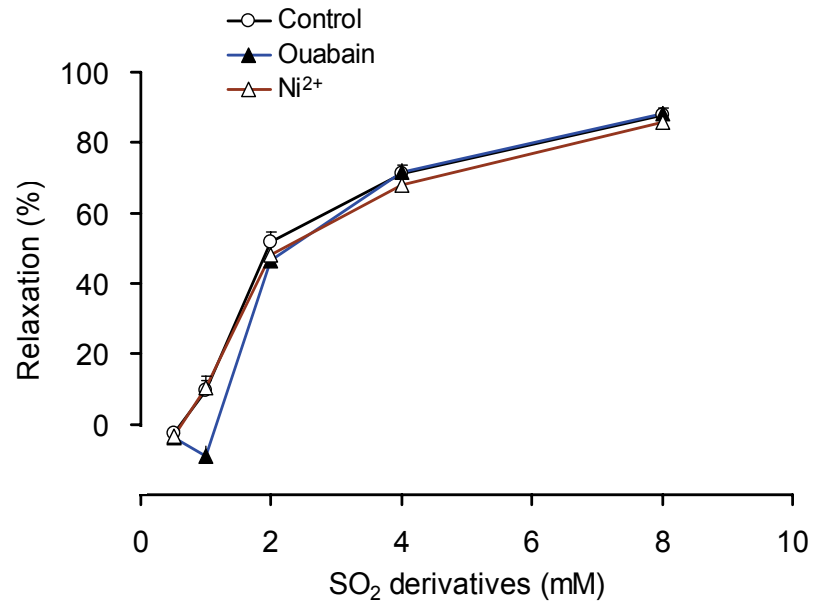

Fig. 5. Relaxation to $\mathrm{SO}_{2}$ derivatives $(0.5-8 \mathrm{mM})$ in endotheliumdenuded aortic rings pre-constricted by $1 \mu \mathrm{M}$ phenylephrine (PE). Rings were incubated with $100 \mathrm{mM}$ ouabain $(\mathrm{n}=14)$ or $30 \mu \mathrm{M}$ $\mathrm{NiCl}_{2}(n=13)$ for 30 min before the addition of PE. Results are mean \pm S.E.M.

endothelium-dependent mechanisms associated with NO. In contrast, the relaxation induced by high doses of $\mathrm{SO}_{2}$ derivatives $(2-8 \mathrm{mM})$ was not changed by endothelium removal or NOS inhibition (Fig. 1), suggesting that the endothelium-independent relaxation was predominant in the presence of a relatively large amount of $\mathrm{SO}_{2}$. Previous report showed that the endothelium-independent relaxation by $\mathrm{SO}_{2}$ derivates was not mediated by $\mathrm{NO}$ (Meng and Zhang 2007). It is not in agreement with our results and need further research.

We further studied the ion channels involved in the potent endothelium-independent vasodilation induced by $\mathrm{SO}_{2}$ derivatives, using pharmacological interventions. It is well known that $\mathrm{K}^{+}$plays a vital role in regulating muscle contractility and vascular tone (Nelson et al. 1995). A rise in $\mathrm{K}^{+}$permeability normally hyperpolarizes cell membrane and thus inhibits $\mathrm{Ca}^{2+}$ influx through VGCCs, resulting in muscle relaxation. To test whether or not $\mathrm{SO}_{2}$ can increase $\mathrm{K}^{+}$permeability, we observed the relaxant response to $\mathrm{SO}_{2}$ derivatives in endotheliumdenuded rings challenged with high $\mathrm{K}^{+}(60 \mathrm{mM})$, a putative blocker for all $\mathrm{K}^{+}$channels (Sang et al. 2003). The vessel tone caused by high $\mathrm{K}^{+}(60 \mathrm{mM})$ was comparable to that by PE $(1 \mu \mathrm{M})$. However, the relaxant response to $\mathrm{SO}_{2}$ derivatives was smaller in rings receiving $\mathrm{K}^{+}$than those receiving $\mathrm{PE}$, suggesting that $\mathrm{SO}_{2}$ derivatives activated $\mathrm{K}^{+}$channels. Balazy et al. (2003) proposed $\mathrm{SO}_{2}$ as a candidate for the unidentified endothelium-derived hyperpolarizing factor (EDHF), based on the facts that of $\mathrm{SO}_{2}$ has a short-life comparable to $\mathrm{EDHF}$ and the formation of $\mathrm{SO}_{2}$ can be stimulated by 
ACh (Balazy et al. 2003). Here we demonstrate that $\mathrm{SO}_{2}$ derivatives relax vascular smooth muscle at least partially through opening $\mathrm{K}^{+}$channels, a well-characterized property of EDHF, supporting $\mathrm{SO}_{2}$ as a candidate for EDHF.

Previous report also studied the mechanisms of the endothelium-independent vasodilation induced by $\mathrm{SO}_{2}$ derivatives and the vasorelaxation was mediated in partly by the inhibition of $\mathrm{Ca}^{2+}$ channels and the signal transduction pathway of $\mathrm{PGI}_{2}$-AC-cAMP-PKA (Meng and Zhang 2007, Meng et al. 2007). In the present study, we further investigated the mechanisms of vasodilation induced by $\mathrm{SO}_{2}$ by using a variety of ion channel interventions such as antagonist of $\mathrm{K}^{+}$channels, $\mathrm{Na}^{+}-\mathrm{K}^{+}$ pump and $\mathrm{Na}^{+}-\mathrm{Ca}^{2+}$ exchange besides voltage-gated $\mathrm{Ca}^{2+}$ channels. Multiple types of $\mathrm{K}^{+}$channels have been identified in vascular smooth muscle cells, among which $\mathrm{K}_{\mathrm{ATP}}, \mathrm{K}_{\mathrm{Ca}}$ and $\mathrm{K}_{\mathrm{V}}$ are relatively predominant (Ferrer et al. 1999). To examine their involvement in $\mathrm{SO}_{2}$-induced relaxation, glibenclamide, TEA and 4-AP were administered in concentrations tested previously (Bolotina et al. 1994, Kitagawa et al. 1994, Kitazono et al. 1995, Murphy et al. 1995, Randall et al. 1991) to block $\mathrm{K}_{\mathrm{ATP}}, \mathrm{K}_{\mathrm{Ca}}$ and $\mathrm{K}_{\mathrm{V}}$, respectively. The relaxation of PE-constricted rings in response to $\mathrm{SO}_{2}$ derivatives was significantly reduced by glibenclamide and TEA, but not by 4-AP. These findings suggest the involvement of $\mathrm{K}_{\mathrm{ATP}}$ and $\mathrm{K}_{\mathrm{Ca}}$ channels in the vasodilating effect of $\mathrm{SO}_{2}$. It is understood that $\mathrm{K}_{\mathrm{ATP}}$ channels play a crucial role under the condition of ischemia and reperfusion, where they are activated to hyperpolarize the membrane and therefore to attenuate injuries. The ability of $\mathrm{SO}_{2}$ to activate $\mathrm{K}_{\mathrm{ATP}}$ channels indicates a potential protective role of $\mathrm{SO}_{2}$ in ischemia-reperfusion.

$\mathrm{SO}_{2}$ derivatives inhibited high $\mathrm{K}^{+}$-induced vasoconstriction (Fig. 2A), indicating that $\mathrm{SO}_{2}$ may act as a $\mathrm{Ca}^{2+}$ channel inhibitor to cause vascular relaxation. In endothelium-denuded aortic rings, $\mathrm{SO}_{2}$ derivatives (0.5-8 mM) reduced $\mathrm{CaCl}_{2}$-induced constriction in a dose-dependent manner, suggesting that $\mathrm{SO}_{2}$ derivatives inhibit $\mathrm{Ca}^{2+}$ influx through VGCCs in smooth muscle cells. In contrast, the whole cell patch-clamp technique revealed an increased voltage-gated L-type $\mathrm{Ca}^{2+}$ current under the treatment with $\mathrm{SO}_{2}$ derivatives in isolated rat ventricular myocytes (Nie et al. 2006). It is indicated that $\mathrm{SO}_{2}$ derivatives may exert different modulations on VGCCs in different cell types.

Sarcolemmal $\mathrm{Na}^{+}-\mathrm{Ca}^{2+}$ exchange plays a significant role in regulating $\left[\mathrm{Ca}^{2+}\right]_{i}$ in smooth muscle cells and thus vessel tone (Motley et al. 1993). The activity of the $\mathrm{Na}^{+}-\mathrm{Ca}^{2+}$ exchanger is coupled to $\left[\mathrm{Na}^{+}\right]$, which is primarily regulated by membrane permeability to $\mathrm{Na}^{+}$ions and $\mathrm{Na}^{+}-\mathrm{K}^{+}$-ATPase activity. Decreased permeability to $\mathrm{Na}^{+}$or increased activity of $\mathrm{Na}^{+}-\mathrm{K}^{+}$pump results in a reduction in $\left[\mathrm{Na}^{+}\right]_{i}$, which in turn stimulates the forward mode of $\mathrm{Na}^{+}-\mathrm{Ca}^{2+}$ exchanger and facilitates vasodilation. Treatment with a $\mathrm{Na}^{+}-\mathrm{K}^{+}$-ATPase inhibitor ouabain or a $\mathrm{Na}^{+}-\mathrm{Ca}^{2+}$ exchanger inhibitor $\mathrm{Ni}^{2+}$ failed to prevent $\mathrm{SO}_{2}$-induced relaxation. This phenomenon suggests that the relaxation by $\mathrm{SO}_{2}$ is unlikely associated with the stimulation of $\mathrm{Na}^{+}-\mathrm{K}^{+}$-ATPase or forward $\mathrm{Na}^{+}$$\mathrm{Ca}^{2+}$ exchanger.

Altogether, the present study showed that $\mathrm{SO}_{2}$ derivatives dose-dependently dilated rat aortic rings via mechanisms that were both endothelium-dependent and independent. NOS activation contributed to the endothelium-dependent relaxation, and the endotheliumindependent relaxation was associated with the activation of $\mathrm{K}_{\mathrm{ATP}}$ and $\mathrm{K}_{\mathrm{Ca}}$, and the inactivation of VGCCs. In addition, $\mathrm{K}_{\mathrm{V}}, \mathrm{Na}^{+}-\mathrm{K}^{+}$-ATPase and $\mathrm{Na}^{+}-\mathrm{Ca}^{2+}$ exchanger were not suggested to be involved in the vasorelaxant response to $\mathrm{SO}_{2}$ derivatives.

\section{Conflict of Interest}

There is no conflict of interest.

\section{Acknowledgements}

This study was supported by grants from the National Basic Research Program of China (No. 2006CB503807) and the National Natural Science Foundation of China (No. 30572190, No. 30600763 and No. 30670760).

\section{References}

BALAZY M, ABU-YOUSEF IA, HARPP DN, PARK J: Identification of carbonyl sulfide and sulfur dioxide in porcine coronary artery by gas chromatography/mass spectrometry, possible relevance to EDHF. Biochem Biophys Res Commun 311: 728-734, 2003.

BHATIA M: Hydrogen sulfide as a vasodilator. IUBMB Life 57: 603-606, 2005. 
BOLOTINA VM, NAJIBI S, PALACINO JJ, PAGANO PJ, COHEN RA: Nitric oxide directly activates calciumdependent potassium channels in vascular smooth muscle. Nature 368: 850-853, 1994.

CHAN YC, LEUNG FP, YAO X, LAU CW, VANHOUTTE PM, HUANG Y: Raloxifene relaxes rat pulmonary arteries and veins: roles of gender, endothelium, and antagonism of $\mathrm{Ca}^{2+}$ influx. $J$ Pharmacol Exp Ther 312: 1266-1271, 2005.

ENGLER MB, ENGLER MM, BROWNE A, SUN YP, SIEVERS R: Mechanisms of vasorelaxation induced by eicosapentaenoic acid (20:5n-3) in WKY rat aorta. Br J Pharmacol 131: 1793-1799, 2000.

FERRER M, MARIN J, ENCABO A, ALONSO MJ, BALFAGON G: Role of $\mathrm{K}^{+}$channels and sodium pump in the vasodilation induced by acetylcholine, nitric oxide, and cyclic GMP in the rabbit aorta. Gen Pharmacol 33: 3541, 1999.

GRIFFITH OW: Cysteinesulfinate metabolism. Altered partitioning between transamination and decarboxylation following administration of beta-methyleneaspartate. J Biol Chem 258: 1591-1598, 1983.

KITAGAWA S, YAMAGUCHI Y, KUNITOMO M, SAMESHIMA E, FUJIWARA M: N ${ }^{\mathrm{G}}$-nitro-L-arginine-resistant endothelium-dependent relaxation induced by acetylcholine in the rabbit renal artery. Life Sci 55: 491-498, 1994.

KITAZONO T, FARACI FM, TAGUCHI H, HEISTAD DD: Role of potassium channels in cerebral blood vessels. Stroke 26: 1713-1723, 1995.

MENG Z, ZHANG H: The Vasodilator effect and its mechanism of sulfur dioxide-derivatives on isolated aortic rings of rats. Inhalation Toxicology 19: 979-986, 2007.

MENG Z, GENG H, BAI J, YAN G: Blood pressure of rats lowered by sulfur dioxide and its derivatives. Inhal Toxicol 15: 951-959, 2003.

MENG Z, LI Y, LI J: Vasodilatation of sulfur dioxide derivatives and signal transduction. Arch Biochem Biophys 467: 291-296, 2007b.

MITSUHASHI H, YAMASHITA S, IKEUCHI H, KUROIWA T, KANEKO Y, HIROMURA K, UEKI K, NOJIMA Y: Oxidative stress-dependent conversion of hydrogen sulfide to sulfite by activated neutrophils. Shock 24: 529-534, 2005.

MOTLEY ED, PAUL RJ, MATLIB MA: Role of $\mathrm{Na}^{+}-\mathrm{Ca}^{2+}$ exchange in the regulation of vascular smooth muscle tension. Am J Physiol 264: H1028-H1040, 1993.

MURPHY ME, BRAYDEN JE: Apamin-sensitive $\mathrm{K}^{+}$channels mediate an endothelium-dependent hyperpolarization in rabbit mesenteric arteries. J Physiol Lond 489: 723-734, 1995.

NELSON MT, QUAYLE JM: Physiological roles and properties of potassium channels in arterial smooth muscle. Am J Physiol 268: C799-C822, 1995.

NIE A, MENG Z: Modulation of L-type calcium current in rat cardiac myocytes by sulfur dioxide derivatives. Food Chem Toxicol 44: 355-363, 2006.

RANDALL MD, GRIFFITH TM: Differential effects of L-arginine on the inhibition by $\mathrm{N}^{\mathrm{G}}$-nitro-L-arginine methyl ester of basal and agonist-stimulated EDRF activity. Br J Pharmacol 104: 743-749, 1991.

SANG SY, YAO X, WONG CM, AU CL, CHEN ZY, HUANG Y: Contribution of $\mathrm{Na}^{+}-\mathrm{Ca}^{2+}$ exchanger to pinacidilinduced relaxation in the rat mesenteric artery. Br J Pharmacol 138: 453-460, 2003.

SHAPIRO R: Genetic effects of bisulfite (sulfur dioxide). Mutat Res 39: 149-175, 1977. 